ESJ Social Sciences

\title{
Assessment Of The Effect Of Socio-Economic Infrasturcture On Rural Economy In Kaduna State, Nigeria
}

\author{
Zakaree S. Saheed, (PhD) \\ Department of Economics, Faculty of Arts and Social Sciences, Nigerian \\ Defence Academy, Kaduna, Nigeria \\ Chima K. Obianuju, (M.Sc) \\ Department of Economics, Air Force Institute of Technology, Kaduna, \\ Nigeria
}

Doi:10.19044/esj.2021.v17n15p157

Submitted: 09 February 2021

Accepted: 07 April 2021

Published: 31 May 2021
Copyright 2021 Author(s)

Under Creative Commons BY-NC-ND

4.0 OPEN ACCESS

Cite As:

Saheed Z.S. \& Obianuju C.K. (2021). Assessment Of The Effect Of Socio-Economic Infrasturcture On Rural Economy In Kaduna State, Nigeria.

European Scientific Journal, ESJ, 17(15), 157. https://doi.org/10.19044/esj.2021.v17n15p157

\begin{abstract}
The paper examines the effect of socio-economic infrastructure of the rural areas on the rural economy in Kaduna State. The study adopts a correlation analysis, a Multicollinearity and Cronbach Alpha Reliability tests as well as regression analysis on primary data. Findings from the study reveal that there is a positive relationship between socioeconomic infrastructure and rural economy, while the multicollinearity test shows absence of high correlation among the independent variables and the Cronbach Alpha confirms internal consistency of the variables. Furthermore, the regression analysis indicates that socio-economic infrastructure, particularly road, electricity supply, market and telecommunication infrastructure all have positive and statistically significant effects on the rural economy. The paper therefore, recommends that governments should increase efforts towards developing the infrastructure in the rural areas in order to facilitate the growth of the economy in the rural sectors.
\end{abstract}

Keywords: Rural Economy, Infrastructure, Market, Electricity, Telecommunication 


\section{Introduction}

The rural economy, which is mainly agriculturally based, holds considerable potentials for job creation, industrial support and economic growth. The agricultural sub-sector of the rural economy comprises economic activities such as crop farming, animal husbandry and dairying, fisheries, poultry and forestry.

Farming remains the major primary economic activity of most rural communities in Africa particularly Nigeria. It serves as the backbone or source of raw materials to other sectors; food supply to the entire population, demand for industrial goods, and supplying of inputs for industries. Hence, the growth of other sectors depends on the growth and development of the rural economy, that is, the agricultural sector, as postulated by Xenopho: (440-355 BC) in Saheed, (2014), that while agriculture prospers, all other arts alike are vigorous and strong. But where the land is forced to remain desert, the spring that feeds the other arts is dried up. Hence, any sudden and profound changes which might affect the farm sector could have severe consequences in terms of social, economic and political stability of any agrarian developing nation (European Commission, 2000).

The non-agricultural sub-sector of the rural economy consists of economic activities relating to agrobusiness which involves buying and selling of agricultural products, which include inputs suppliers, agroprocessors, traders, exporters and retailers. More so, in the agricultural sector, there are farm activities, as well as off-farm activities ranging from subsistence farming to large commercial agrobusiness that supplies the global markets through regional and national linkages with other sectors (International Labour Organisation, 2008).

In Kaduna State, majority of the rural people actively engage in both food and cash crops farming. These include cotton, groundnut, tobacco, ginger yam, cassava, maize, beans, guinea corn, and millet: Besides, a significant number of households are involved in livestock production like poultry, cattle, sheep, goats and pigs. The traditional livestock production systems predominate the sector with essentially low input-output systems. However, the modern livestock production systems in the state expend more capital and utilize mostly purchased variable inputs such as feeds, drugs, vaccines etc, with significantly higher productivity compared to the traditional production systems (Kaduna State Government, 2013).

The commercial poultry production sector is dominated by medium and small-scale operators by Nigerian standard. This is in spite of the potentials of the state in the poultry sector, and given the fact that the state is a major producer of maize; sorghum; groundnut and soyabean, all of these are major poultry feed ingredients.

Most of the fish outputs of the state come from the wild, which is 
gradually declining, hence aquaculture is being promoted. The aquaculture itself depends on fingerlings and compounded ration. Both of which can be produced in the state with minimal investments, since most of the ingredients for compounding the ration are produced within the State.

Some of the challenges inhibiting the demonstration of potentiality of rural areas include: production system that is characterized by small-scale producers that is also depends on low adoption of improved inputs and practices resulting in low productivity; post-season rural unemployment; lack of adequate infrastructure like good road networks, electricity supply, telecommunication networks, markets; and limited access to financial services.

Roads networks are constructed to connect human communities and facilitate access to natural resources available in the rural areas and transportation of harvest from the farm to markets. However, the rural environment that is being perceived as the engine of economic growth of the country, the main supplier of food to the urban population and the custodians of the ecosystems, remain inaccessible due to lack of roads. In many of the rural areas, the farmers and their families trek several kilometers carrying heavy loads from the farm to market places.

Despite the importance of electricity supply, that is considered as the hub of economy and the engine room of industrial development, according to the World Bank figures, only about 59.3 per cent of the Nigerian population have access to electricity as at 2016-2017. However, the situation is even worse in the rural communities across the country. A situation where most of the rural communities stay in darkness with no electricity supply (UNDP, 2019). In Kaduna State, electricity supply is on average in some cities but inadequate in the rural communities. Hence, in the rural areas, farmers have to depend highly on privately owned generators to operate their irrigation systems. More so, many farmers cannot preserve their farm products. So, most often the harvest are sold at very cheap prices, to avoid total loss, while many goods are wasted.

Availability of standard agricultural markets for the rural farmers is another challenge impending the development of the rural economy. Farmer markets are traditional open places in the rural areas where agricultural and domestically produced goods are traded and people from the neighbouring communities can converge to transact business, particularly agribusiness. Since there are no stores or warehouses, the farmers trek several kilometers with their products to the market, and any unsold goods are returned to the village via the same channel. In such a market situation, the rural farmers are often the price takers and are always at the mercy of the middlemen who are the price makers. The stress of returning home with unsold products and fear 
of wastage leave the farmers with no option than to sell their products at giveaway prices, thereby reducing the income of the farmers.

Meanwhile, communication infrastructure like internet services, mobile and land phone networks, television and radio transmission stations (Aigbokha,1999), that are necessary for growth and development of the rural economy are not available in the rural communities. Hence the rural dwellers and their products are disconnected from the urban and global economy, making it very difficult for the rural dweller to link the urban centre and tap from the large markets through the internet and web.

In response to the developmental challenges of the rural area and development of the rural economy, various governments have formulated several policies and programmes but implemented few towards the development of the rural areas. For example, the first National Development plan spanned between the years 1962-1968 proritised agriculture with emphasis on introduction of modern agricultural methods through farm settlements, co-operative (nucleus) plantations, supply of improved farm implements, and a greatly expanded agricultural extension service.

Furthermore, the Directorate of Food, Roads and Rural Infrastructure (DFRRI) was established in recognition of the benefits associated with basic needs such as food, shelter, potable water, etc. The integrated approach to rural development provided for the necessary basic infrastructures that stimulated the growth of agro-allied small-scale enterprises in rural areas.

The Nigerian Rural Electrification Agency (REA) was created by the Electric Power Sector Reform Act in 2006, with the aim of facilitating the provision of affordable power supply for residential, commercial, industrial and social activities in the rural and peri-urban areas of the country.

In an effort to improve the rural economy in Kaduna State, the state government, on its part, has been providing support to farmers in terms of extension advisory services through the recommended extension agents. It is also providing input like improved seeds, agrochemicals, credit facility, tractors services and fertilizers at subsidized rates. In addition, the irrigation facilities put in place by the Government and Fadama III Programme have been contributing to dry season farming. Public intervention in livestock development is focused on the provision of support services such as pests and disease control, veterinary public health, poultry development, beef and dairy animal development, and grazing reserve development (KDSG, 2013). The state government has also engaged in improving the economic infrastructure in the rural areas of the state. However, all these efforts by various governments towards improving capital infrastructure in the rural areas, have not been able to provide much effect on the economy of the rural areas of the state. Hence, the effectiveness of government policy in this direction is yet to be ascertained. 
Given the foregoing, this paper aims at empirically examining the effect of socio-economic infrastructure on the rural economy in Kaduna State, Nigeria.

To this end, the paper is organized into five sections. Next to the introduction is section II, which focuses on the review of relevant literatures. Section III discusses the methodology. Section IV analyses and interprets the data, while section $\mathrm{V}$ summarises the findings and offer some policy recommendations.

\section{Literature Review}

Conceptually, Hirschman (1958) describes infrastructure as those basic facilities which play a critical role in creating investment opportunities for other industries. Without the existence of this infrastructure, the functionality of other primary, secondary and tertiary activities would be a mirage. Infrastructure is the facilitator to production activities that serves as a foundation stone for the growth of both the rural and urban economy. Hence, in the context of rural economy, infrastructure can be seen as the supporting system that facilitates the growth of the rural economy, and assists the economic agents in the rural area to enable them explore the opportunities in the economic environments.

UKEssay (2018), describes economic infrastructure as all such elements of economic change including power, transport and communication, that serves as the foundation for the growth of the economy. Effective electricity supply tends to facilitate the pace of production activity while an effective transportation system would make the movement of goods and people from one place to the other, and effective means of communication would help to facilitate marketing, and help to link-up various markets.

Meanwhile, Reddy (2018) views economic infrastructure as the essential amenities that support the development of other sectors of the economy. These amenities assist in improving the overall productivity of the economy, and assist in smooth running of all the sectors of the economy.

Social infrastructure can be described as core elements of social change including academic institutions and health facilities that serve as a building block for the process of social development of a country. Social development involves human resource development, which implies the development of healthy, skilled and efficient human beings, (UKEssay, 2018) for the growth and development of the nation.

Theoretically, the study is anchored on unbalanced growth theory propounded by Hirschman who believes that owing to unavailability of adequate resources in less developed countries, creating imbalances in the system would be the best strategy for development. According to the theory, rather than investing in the sector simultaneously, investment should be made 
in the strategic sector of the economy that will create a trickle-down effect on other sectors to develop. For instance, public investment in social overhead capital like roads, electricity, transport and communication infrastructures will stimulate the growth of other sectors of the economy.

Alternatively, initial investment according to the theory, could create shortages, thereby providing the incentive for other sectors to meet needs for backward linkages. For example, the development of a textile factory would create demand for more cotton, and the establishment of shoe factory would create a demand for leather. The appropriate direction would vary with the linkages that were most significant for a particular country. However, in case investment is made first in directly productive activities, the private investors would be facing a lot of challenges if there is no adequate or there is lack of social overhead capital (infrastructure). It may be difficult for any industry in a particular region to grow if social overhead capital facilities or infrastructures are not available. Thus, excess social capital overhead or infrastructures will be a pressure-relieving for the rural economy.

Empirically, several scholars within and outside the country, have explored the relationship between socio-economic infrastructures and rural economy. For instance, Daud, et.al. (2018), assessed the infrastructures' effect on food crop production profitability among rural farming households in Oyo State, Nigeria. Using a Descriptive Statistic, Budgeting Analysis (BA) and Ordinary Least Square regression (OLS), the result indicates that rural infrastructure is essential to the output of agriculture production in the study area.

Adeniyi, et.al. (2018), assess road transportation impact on rural development, with a view to determine the contributions of road transport to rural development in Akure North Local Government of Ondo State, Nigeria. Systematic Sampling technique was used to select and administered questionnaire to about 240 respondents. Findings from the study revealed that the rural roads are in poor condition which has an influence on the cost of transporting farm produce and the economy of the area. On their part, Luis and Alejandro (2018) estimate the impact of public infrastructure on economic growth in the eight regions of Oaxaca for the period 2003-2013. The study adopted a fixed-effects model, and the results indicate that investment in infrastructure has been insufficient and misallocated. However, the social infrastructure shows the greatest impact on growth.

Palei (2015), examines the degree of the influence of infrastructure on national competitiveness. The study also attempts to identify and discuss the key infrastructure factors that determine national competitiveness, which in turn influence positively on the total results of industrial policy. The finding from the study showed that national competitiveness is influenced basically by the level of institutional development and other seven factors, including 
infrastructure that in turn is determined mainly by the quality of roads, railroad infrastructure, air transport and electricity supply.

Rahman (2014), investigates the impact of rural infrastructure on making a choice between farm and non-farm enterprises vis-à-vis income from Bangladeshi rural households. The study used a bivariate Tobit model, and the result reveals that rural infrastructure has a negative and statistically significant impact on enterprise choices vis-à-vis income. Other factors like household assets, farm size, farming experience, livestock resources, and education were found to also exert a significant influence.

More so, Olufemi, et.al. (2013), investigate the effect of infrastructural development on economic growth. The study adopts a simple model of an economy with foreign investment and public infrastructure with a diversified equilibrium where the economic growth could not translate to economic development due to lack of infrastructure, high poverty rate, unemployment etc. Hence, it is concluded that infrastructure has a significant effect on economic development.

Oguzor, (2011) examines the effect of social infrastructural facilities in promoting rural development in Imo State. The study used primary data sourced through questionnaire administered to respondents in eighteen communities of the state. Findings from the study revealed that the presence of infrastructure in the state has a significant effect on economic activities in the state.

Meanwhile, Ashagidigbi, et.al. (2011) investigated the effect of infrastructure on farmers productivity in Osun state, using multistage random sampling procedure to source for primary data. The findings from the study shows that fertilizer, farm size and distance to major roads are the major determinants of farmers' productivity in the area.

Achjar and Panennungi, (2009) examine the impact of the rural infrastructure on rural poverty reduction, using a probit model on data obtained from six districts in Indonesia. The findings show that good roads in the rural community and the level of education level of household's head tend to reduce the probability of the household being poor. It implies that, both physical and non-physical infrastructure (human capital) in the rural community have a significant impact on poverty reduction in the area. Furthermore, it reveals that rural infrastructure development, whether physical (roads, bridges, electricity, irrigation, among others) or non-physical (education and health), will not only improve the rural economy, but also plays a direct and indirect role in reducing poverty. 


\section{Methodology}

\section{Area of Study}

Kaduna State was founded in 1976, when the then North Central State with capital at Kaduna was renamed Kaduna State. It shares common borders with Zamfara, Katsina, Niger, Kano, Bauchi, Nasarawa, Plateau States, and the Federal Capital Territory. The total landmass of the State is estimated at $46,053 \mathrm{sq} \mathrm{km}$ which is about $5 \%$ of the total land area of Nigeria. It has Rivers Kaduna, Kogum, Gurara, Matsirga and Galma as the major rivers in the state.

The population of the state according to 2006 census stands at $6,113,503$ with the majority of the people living in urban and semi urban towns in the state. The rural population is estimated at 3,682,034 (2006 Census). The economy of Kaduna state is mainly agriculture with the majority of the people actively engaged in farming and agribusiness. Some of the population also involve livestock such as poultry, cattle, sheep, goats and pigs (KSG, 2013).

\section{Research Design}

The descriptive research design was used in this study, and the survey method was adopted since it is considered suitable for the study because it is a very valuable tool for assessing opinions and trends. It consists of a predetermined set of structured questionnaires built on 4-point Likert scale to collect information from a representative sample of the population of selected rural communities in Kaduna State. However, it would be unrealistic to study this large group of people whose population may be undetermined due to inaccessibility of information. Therefore, using Taro Yammanne method of finite size sample determination, a sample of 399 respondents was randomly selected from the population across rural communities in the state. The study utilized mainly primary data obtained through the administration of structured questionnaire.

\section{Model Specifications}

The model for the study is adapted from the work of Palei (2015) who observed that the competitiveness of a nation is influenced majorly by the level of its institutional development and the state of its infrastructures. The level of infrastructure itself is determined by the quality of roads, railroad infrastructure, air transport and electricity supply. Based on his findings, the model is represented thus:

$$
\begin{aligned}
& \mathrm{Y}=f(\mathrm{Ifr}) \ldots \ldots \ldots \ldots \ldots \ldots \\
& \mathrm{Ifr}=f(\mathrm{RN}, \mathrm{Rr}, \mathrm{AT}, \mathrm{ES})
\end{aligned}
$$

Substituting equation (2) in equation (1):

$$
\mathrm{Y}=f(\mathrm{RN}, \mathrm{Rr}, \mathrm{AT}, \mathrm{ES})
$$

Where:

$$
\begin{aligned}
& \mathrm{Y}=\text { Global Competitiveness } \\
& \text { Ifr = Infrastructure }
\end{aligned}
$$




$$
\begin{aligned}
& \mathrm{RN}=\text { Road Network } \\
& \mathrm{Rr}=\text { Railroad } \\
& \mathrm{AT}=\text { Air transport } \\
& \mathrm{ES}=\text { Electricity Supply. }
\end{aligned}
$$

In the context of this study, competitiveness of a nation is substituted for rural economy and in line with the objective of the study, the model is therefore modified thus:

\section{Model I: Effect of Socio-Economic Infrastructure on Rural Economy:}

$$
\begin{aligned}
& \mathrm{RE}=f(\mathrm{SEI}) \ldots \ldots \ldots \ldots \ldots \ldots \ldots \\
& \mathrm{SEI}=f(\mathrm{RN}, \mathrm{EL}, \mathrm{MT}, \mathrm{TCN}) .
\end{aligned}
$$

Substituting equation (5) in equation (4):

$\mathrm{RE}=(\mathrm{RN}, \mathrm{ES}, \mathrm{MT}, \mathrm{TCN})$

Modifying equation (6) in stochastic form as:

$$
\mathrm{RE}=\beta_{0}+\beta_{1} \mathrm{RN}+\beta_{2} \mathrm{EL}+\beta_{3} \mathrm{MT}+\beta_{4} \mathrm{TCN}+\mu
$$

Where:

RE represent Rural Economy

SEI represent Socio-Economic Infrastructure

RN represent Road Network

EL represent Electricity Supply

MT represent Market Infrastructure

TCN represent Telecommunication Network

\section{Empirical Results and Discussion}

The results of descriptive analysis are reported in this section.

Table 1. Results of descriptive analysis

\begin{tabular}{|l|l|l|l|l|l|}
\hline Variable & Observation & Mean & $\begin{array}{l}\text { Standard } \\
\text { Deviation. }\end{array}$ & Minimum & Maximum \\
\hline RE & 300 & 3.298 & .568 & 1.3 & 4 \\
\hline RN & 300 & 3.443 & .590 & 1 & 4 \\
\hline EL & 300 & 3.388 & .626 & 1.3 & 4 \\
\hline MT & 300 & 2.985 & .721 & .6 & 4 \\
\hline TC & 300 & 3.134 & .559 & 1.3 & 4 \\
\hline
\end{tabular}

STATA 13 Outputs

The descriptive statistics shown in Table 1, reveals that variables Rural Economy (RE), Electricity Supply (EL) and Telecommunication (TC) have a mean of about 3, with minimum of 1.3 and maximum of 4. Road Network variable has a mean of about 3.4 with minimum of 1 and maximum of 4 , while Market infrastructure variable has a mean of about 3 with minimum 0.6 and maximum of 4 . The standard deviations of all the variables are less than one, indicating that the individual responses are concentrated around the mean. In other word, they are less than one point away from the mean. Meanwhile, the MT is rated least of all the variables with a mean of 2.99, Minimum and Maximum at of 0.6 and 4 respectively. However, the standard deviation at about 0.7 , is also clustered around the mean. 
Table 2. Results of correlation analysis

\begin{tabular}{|l|l|l|l|l|l|}
\hline & RE & RN & EL & MT & TC \\
\hline RE & 1.000 & & & & \\
\hline RN & $0.491^{*}$ & 1.000 & & & \\
& 0.000 & & & & \\
\hline EL & $0.472^{*}$ & $0.543^{*}$ & 1.000 & & \\
& 0.000 & 0.000 & & & \\
\hline MT & $0.363^{*}$ & $0.197^{*}$ & $0.312^{*}$ & 1.000 & \\
& 0.000 & 0.006 & 0.000 & & \\
\hline TC & $0.432^{*}$ & $0.371^{*}$ & $0.435^{*}$ & $0.495^{*}$ & 1.000 \\
& 0.000 & 0.000 & 0.000 & 0.000 & \\
\hline
\end{tabular}

STATA 13 Outputs

The results of correlation analysis in Table 2 reveals Rural Economy (RE), with a coefficient of 0.491 has a positive and moderate relationship with Road Network (RN). The p-value of 0.000 shows that the relationship is statistically significant. More so, with a moderate correlation of 0.472 and pvalue of 0.0000 , the results further reveal a moderate positive and statistically significant relationship between Electricity (EL) and Rural Economy. Market Infrastructure (MT), with a coefficient of 0.363 and p-value of 0.0000 signifies a moderate positive and statistically significant relationship with Rural Economy, while Telecommunication (TC) also shows a moderate positive and statistically significant relationship with National security, with a coefficient and p-value of 0.432 and 0.000 respectively.

Meanwhile, the coefficient value of all the variables indicates absence of multicollinearity among the independent variables that would have weakened the precision of the estimate coefficient, which might in turn affect the statistical power of the regression model. To further confirm absence of correlation among the independent variables, a multicollinearity test is conducted.

Table 3. Results of VIF \& Tolerance Level

\begin{tabular}{|l|l|l|}
\hline Variable & VIF & $1 /$ VIF \\
\hline EL & 1.51 & 0.663298 \\
\hline TC & 1.46 & 0.684577 \\
\hline RN & 1.41 & 0.707662 \\
\hline MT & 1.30 & 0.769175 \\
\hline Mean VIF & 1.42 & \\
\hline
\end{tabular}

STATA 13 Outputs

The results of the multicollinearity test in Table 3 reveals that the VIF for all the variables is closer to 1 , which is an indication that there is absence of high correlations among the independent variables. Hence changes in any of the variable cannot be attributed to shifts in another variable. The result confirms the absence of correlation shown in the results in Table 2. 
Table 4. Results of reliability test using Cronbach Alpha

\begin{tabular}{|l|l|l|l|l|l|l|}
\hline Item & $\begin{array}{l}\text { Observatio } \\
\mathrm{n}\end{array}$ & Sign & $\begin{array}{l}\text { item-test } \\
\text { correlation }\end{array}$ & $\begin{array}{l}\text { item-rest } \\
\text { correlation }\end{array}$ & $\begin{array}{l}\text { average } \\
\text { interitem } \\
\text { covariance }\end{array}$ & Alpha \\
\hline RE & 300 & + & 0.746 & 0.526 & .150 & 0.711 \\
\hline RN & 300 & + & 0.702 & 0.522 & .158 & 0.734 \\
\hline EL & 300 & + & 0.758 & 0.589 & .143 & 0.710 \\
\hline MT & 300 & + & 0.683 & 0.440 & .157 & 0.772 \\
\hline TC & 300 & + & 0.744 & 0.594 & .151 & 0.712 \\
\hline Test scale & & & & & .152 & 0.770 \\
\hline
\end{tabular}

STATA 13 Outputs

The Cronbach Alpha test shows the internal consistency or the reliability of the data. The results in Table 4 show alpha coefficient of the variables to be 0.770 , suggesting that the variables have internal consistency, and can be affirmed to have good reliability. The implication of which shows that the test actually measures the effect of all the independent variables (RN, EL, MT and TC) on the Rural Economy (RE).

Table 5. Results of regression analysis

\begin{tabular}{|l|l|l|l|l|l|l|l|}
\hline RE & Coef. & Std. Err. & T & & P $>$ t & {$[95 \%$ Conf. } & Interval] \\
\hline RN & .285 & .054 & 5.26 & & 0.000 & .178 & .391 \\
\hline EL & .173 & .053 & 3.26 & & 0.001 & .069 & .277 \\
\hline MT & .132 & .042 & 3.11 & & 0.002 & .049 & .216 \\
\hline TC & .159 & .059 & 2.70 & & 0.007 & .043 & .274 \\
\hline _cons & .840 & .192 & 4.37 & & 0.008 & .461 & 1.218 \\
\hline Prob $>$ F $=0.000$ & & & & & & \\
\hline $\mathrm{R}^{2}=0.3636$ & & & & & & \\
\hline Adj R $\mathrm{R}^{2}=0.355$ & & & & & \\
\hline
\end{tabular}

STATA 13 Outputs

$$
\begin{gathered}
\mathrm{RE}=\beta_{0}+\beta_{1} \mathrm{RN}+\beta_{2} \mathrm{EL}+\beta_{3} \mathrm{MT}+\beta_{4} \mathrm{TCN}+\mu \\
\mathrm{RE}=0.840+0.285 \mathrm{EL}+0.173 \mathrm{MT}+0.132 \mathrm{MT}+0.159 \mathrm{TCN} \\
(4.03) \quad(4.42) \quad(3.13) \quad(2.90)
\end{gathered}
$$

The results in Table 5 reveal the effect of Socio-economic infrastructure on Rural Economy in Nigeria. The results reveal F-stat value of 0.0000 , indicating a very good fit for the regression model, and all the variables (RN, EL, MT and TC)' coefficients are jointly statistically significant. Furthermore, the R-Square indicates that about 36.4 percent of the variation in rural economy can be explained by factors in the model, while about 63.4 percent can be attributed to other factors outside the model.

Furthermore, the results also reveal that Road Network (RN), with a coefficient of 0.285 , t-stat of 5.26 and p-value of 0.000 , has a positive and statistically significant impact on the rural economy. It implies that one percent improvement on road infrastructure tends to improve rural economy by about 0.29 percent, provided all other factors remain constant. 
More so, electricity supply (EL) shows a coefficient of 0.17 , a t-value of 3.26 and p-value of 0.001 , which implies that electricity infrastructure, has a positive and statistically significant effect on rural economy. With one percent improvement in electricity infrastructure, the rural economy tends to rise by about 0.17 percent provided all other factors remain constant. Meanwhile, Market infrastructure shows a coefficient of 0.132 , t-value of 3.11 and p-value of 0.002 indicating that market infrastructure has a positive and statistically significant effect on rural economy. By implication, if other factors remain unchanged, a percent improvement in market infrastructure in the rural area, the rural economy tends to increase by about 0.13 percent.

Meanwhile, the result also reveals that Telecommunication infrastructure (TC) shows a coefficient of 0.159 , t-stat of 2.70 and p-value of 0.007. This indicates that Telecommunication infrastructure (TC) has positive and statistically significant effect rural economy. All other factors being constant, one percent improve in telecommunication infrastructure tends to lead to about 0.16 percent growth in rural economy.

\section{Discussion of Findings}

The results from data analysis indicate that socio-economic infrastructure in the rural areas has a positive and statistically significant effect on the growth of the rural economy in Kaduna State, Nigeria. The result agrees with apriori expectation. All the infrastructure: road infrastructure, electricity supply, market infrastructure and telecommunication infrastructures that are considered in the study, showed a strong effect on rural economy. These infrastructures tend to improve the productivity of the rural sector and consequently improve the rural economy. The results agree with the findings of Oguzo (2011), who observed that social infrastructure in Imo State enhanced economic activities.

Road infrastructure in the rural area has a statistically significant effect on the growth of the rural economy. Good road network is expected to openup rural areas for easy access and movement of goods from the producers in rural area to the final consumers in the urban centres and other parts of the country. It also helps to facilitate input supplies to the industrial sector, that will in turn increase the productivity, thereby leading to the growth of the rural economy. The finding agrees with the findings of Achjar and Panennungi, (2009) who observed that rural physical infrastructures development like roads, bridges, electricity and irrigation improve rural economic capability.

Electricity supply in the rural area is found to be statistically significant in explaining rural economy in Kaduna State, Nigeria. This is not unconnected with the fact that electricity infrastructure is key to the growth of any economy. It is very essential in almost every aspect of economic activities, particularly where all the machines and other modern technologies used in the process of 
transforming raw materials to finished or semi-finished goods use electricity. Hence the growth of the economy is determined by increase in output, and output itself is affected by electricity supply, therefore, it can be affirmed that electricity supply is very significant in the growth of rural economy.

Market is any set up that facilitates transactions in economy, whereby potential buyers and sellers meet to exchange goods or services. In the rural communities, it is usually a physical location where economic agents gather to exchange products of their economic activities including buying and selling. Though, in the modern world, a market is no more just a meeting point for buyers and sellers, rather it represents a set of all the potential buyers and sellers in an environment. In whichever way it is perceived, market infrastructure has proven to be essential for the growth of the rural economy. A production is said not to be complete until the products or goods get to the final consumers, and one of the means through which the products can be accessed by the consumer is the market. Hence, market infrastructure is significant in explaining the growth of the rural economy.

The results also indicate that telecommunication in rural areas has a positive and statistically significant impact on the rural economy in Kaduna State, Nigeria. Telecommunication infrastructure like telephone networks, mobile phone networks, and internet service can help to accelerate the growth of the rural economy. For instance, the internet can be used as a powerful information and sales channel by the producers to augment their geographical outreach, to promote their products to potential consumers worldwide. Through developing a website, even the small-scale entrepreneurs can list their products, services and other information of interest to potential consumers. In the same vein, the consumers, through the internet, can practically have access to greater information practically anything from anywhere. Hence, buyers with ease, can place and receive orders online from varieties of available goods and services from anywhere in the world.

\section{Conclusion and Recommendations}

The objective of this paper is to establish a model that explains the effect of socio-economic infrastructure on rural economy and specifically to assess the effect of road infrastructure, electricity, and market infrastructure and telecommunication infrastructure on rural economy in Kaduna State, Nigeria. Based on the results obtained from analysis of the primary data collected from the study area, it is observed that each of the road network, electricity, market and telecommunication infrastructures is statistically significant in explaining rural economy, particularly in Kaduna State of Nigeria. Hence, it can be succinctly concluded that socio-economic infrastructure development in the rural areas has a positive effect that is statistically significant on rural economy. Given the foregoing, the study therefore, recommends thus: 
1) Construction of new roads and the repair works of the existing ones in the rural areas should be carried out by the state government, to create easy access to raw materials in some of these rural areas, to facilitate easy movement of goods or products from the rural communities to markets in urban centers.

2) Availability of efficient electricity will stimulate the growth of small-scale industries like food processing, flour mills, among others in the rural areas. Hence, the government must ensure that its rural electrification programme get to the grassroot, especially the villages to stimulate the growth of the rural economy.

3) Market infrastructure is one of the means through which rural producers can get their products across to the consumers in exchange for money and also a means of obtaining essential goods or services for necessary their wellbeing. Hence the government should establish standard agricultural markets in the rural communities. This will make it easier for the rural dwellers to move their products from the farm to the market and also encourage urban-rural movement rather than rural-urban movement.

4) Furthermore, the government should extend information and communication technology networks to rural areas to help in connecting the rural areas to the urban centers. Provision of communications infrastructure like mobile phone and internet networks in these communities will help the rural producers to market their products to the outside world, and also have access to other information or services that may assist in improving their productivity.

\section{References:}

1. Adeniyi, J.O., Akinrimide, Y. and Abiodun, A.L. (2018). Analysis of road transportation impact on rural development in Nigeria: A study on Akure North Local Government Area, Ondo State. International Journal of New Technology and Research (IJNTR) 4(3), 102-110.

2. Aigboka,B. E. (1999).Evaluating investment on basic infrastructure in Nigeria. Proceedings of the Eighth Annual Conference of the Zonal Research Units (Organised by Research Dept. Central Bank of Nigeria, at Hamdala Hotel,Kaduna,11 -15 June,1999),p.208

3. Ashagidigbi W. M, Falusi, A.O. and Awopeju, S.O (2011). The Effects of Rural Infrastructure Development on Crop Farmer's Productivity in Osun State. World Rural Observations, 3(1):48-58].

4. Daud, S. A., Omotayo, A. O., Aremu, A. O., \& Omotoso, A. (2018). Rural infrastructure and profitability of food crop Production in Oyo 
State, Nigeria. Applied Ecology and Environmental Research 16(4):4655-4665.

5. European Commission, (2000). Agriculture's Contribution to Rural Development. International Conference on Non-Trade Concerns in Agriculture Ullensvang, Norway, 2-4 July 2000.

6. International Labour Organisation, (2008). Rural Economy. https://www.ilo.org/global/topics/dw4sd/themes/rural-economy/lang-en/index.htm ILC. Report of the Committee on Rural Employment. Geneva : ILO, 2008.

7. KDSG (2013). State development Plan. 2014-2018. Ministry of economic planning publication.

8. Luis Enrique Rojas-Ramírez and Alejandro Molina-Vargas (2018). Public infrastructure and its importance for economic growth: the case of oaxaca (Mexico). ecos.econ. vol.22 no.46 Medellín. http://www.scielo.org.co/scielo.php?script=sci_arttext\&pid=S165742062018000100004

9. Nuzul Achjar \& Maddaremmeng A. Panennungi, (2009). The Impact of Rural Infrastructure Development on Poverty Reduction in Indonesia. Economics and Finance in Indonesia, 57, p.339-348.

10. Oguzor, N.S. (2011). A spatial analysis of infrastructures and social services in rural Nigeria. GeoTropico, 5 (1), Articulo 2: 25-38.

11. Olufemi, E.A., Olatunbosun, A..J., Olasode, O.S. \&I.G. Adeniran (2013). Infrastructure development and its effect on economic growth: The Nigerian Perspective. European Scientific Journal, 9 (31) ISSN: $1857-7881$

12. Palei, T. (2015). Assessing the impact of infrastructure on economic growth and Global Competitiveness. Procedia Economics and Finance 23 (2015) $168-175$

13. Rahman, S. (2014). Impact of rural infrastructure on farm and nonfarm enterprise choice and income in Bangladesh. The Journal of Developing Areas, 48(1), 275-290

14. Reddy N. (2018). Economic Infrastructure - Intro, Types, Significance,. https://www.toppr.com/bytes/economic-infrastructure/

15. Saheed, Z.S. (2014). Impact of agricultural credit guarantee scheme fund (ACGSF) on domestic food supply. British Journal of economics, management and trade. 4 (8), 1273 - 1284.

16. UKEssays. (2018). Economic and Social Infrastructure. https://www.ukessays.com/essays/economics/economic-and-socialinfrastructure-economics-essay.php?vref $=1$

17. UNDP (2012). Rural development for developing economies. The United Nations Development Programme, Washington DC. 